\title{
Assessment of Utilizing of the Perception on Environmentally Friendly Products
}

\author{
Tetsuo Nishi \\ Tokyo Institute of Technology, 2-12-1-W9-25 Ookayama, Meguro-ku, Tokyo 152-8552, Japan
}

\begin{abstract}
Nowadays, the majority of people believe that solving the environmental problems should start with the adoption of sufficient and convincing education programs and then enhance environmentally friendly consciousness. This would eventually lead to the final solution. However, the problem solution scenario is not so simple. Naturally, consumers' behaviors are difficult to be predicted and they do not always necessarily follow the rational-mind purchasing criteria. When purchasing food, mostly they choose the product because of its taste, quality and price, and lastly maybe due to its environmental friendliness from one hand. From the other hand, the manufacturer's priority is for the quantity sold and profit rather than product's environmental safety. Recently, is it possible to change consumers' mind-set and make them behave and select products in environmentally friendly manner? The author thinks it's possible and the key is the kind of trigger through heart-moving incentive. This paper focuses on the Acorn Point System Project, which incorporates carbon foot print and carbon offset scheme, and argues about methods that can be used effectively and efficiently to facilitate those environmentally unmotivated companies and consumers to adopt environmentally friendly mind-set and shift to more proactive ones. This paper has confirmed that the most effective factors to stimulate unmotivated consumers to better acquire environmentally friendly mind-set, which leads to proactive eco-mind products purchasers and activists, are: (1) non-environmental product benefits must be stressed even for the environmentally friendly products; (2) environment consideration project incubation involves various interest parties and mechanism of shared satisfaction as a team; (3) start with small scale community project, which enables participants to recognize their project contribution.
\end{abstract}

Key words: Environmental consciousness, motivation, incentive, public benefit, private benefit, interest parties.

\section{Introduction}

While environmental problems, including global warming, are becoming more and more serious, there exists such frustrating reality of very weak penetration of environmentally friendly products. According to the result of an internet survey conducted by the Ministry of Environment in Japan in 2012, the percentage of person who purchased environmentally friendly products positively was only $11.7 \%$ [1]. The author thinks that this is because consumers choose products not because of environmental friendliness but lower price and higher quality, which better satisfy consumer wants. And manufacturers also place priority on potential sales volume and sales profits rather than environmental safety in new product

Corresponding author: Tetsuo Nishi, Ph.D. student, research fields: environmental and food consciousness, social business, social system. development and business management.

Thus, as a breakthrough in facilitating unmotivated consumers to purchase more environmentally friendly products and pushing those manufacturers with less eco-conscious mind to be more proactive in research and development investment and utilization of new environmentally friendly products, Ministry of Economy, Trade and Industry (METI) in Japan launched Supporting Carbon Footprint (CFP) Offset Point Promotion Project, commonly known as Acorn Point Project [2]. Based on the experience acquired from the project, this paper aimed to develop thoughts on how to better implement environment-related educational program and promote solution methodology for the environmental problems and finally to address breakthrough effective solution methods. 


\section{Methods}

\subsection{Internet Survey}

In this paper, an annual internet survey results were used for studying consumers' consciousness and behavior [3]. Surveys during the period 2009-2014 were conducted by Initiative for Circular Flow Society, which was a research group of environmental staff members in Japanese main companies and the author of this paper was the chairman of this group. Fifty questions were interviewed concerning attention to social problems, important reasons for the purchase, implementation situation of environmental activities and reasons for the adoption. The surveys have been designed and conducted since 2009 among male and female respondents aging over 20 years old and living in Japan, with effective completed responses of more than 1,000 which meets pre-designed target sample splits in line with the universe.

The author used the national population census, which Statistic Bureau, Ministry of Internal Affairs and Communications in Japan have conducted every five years as the universe. The census conducted in 2005 [4] was utilized as the universe of surveys during the period 2009-2011 and the census conducted in 2010 [5] was utilized as the universe of surveys during the period 2012-2014.
Samples of 800,000 people have been extracted from INTAGE sample panel, based on the quota allocation by gender (male, female), age (20-29, 30-39, 40-49, 50-59, over 60) and area (Hokkaido/Tohoku, Kanto/Keihin, Chubu, Kinki, Chugoku/Shikoku, Kyusyu/Okinawa) in line with the splits of universe. Table 1 shows the requested sample number, the collected sample number and the collected rate in each survey.

Tables 2-4 shows the comparison between the collected rate of the internet survey in 2014 and the population rate of the census in 2010 by gender, age and area. The composition ratio of the collection sample of the internet survey and the population composition ratio of the national population census are almost similar. The comparison ratios of the internet surveys from 2009 to 2013 and the population composition ratio of the census are approximately similar as in 2014.

\subsection{Acorn Point Mark Project}

In order to quantify the effectiveness of such non-environmental benefits, as tastes and corporate sales profit in the environmental context, the first social experimental project called Acorn Point Mark Project, whose objective is to promote carbon offset product attaching with clearly identifiable Acorn point

Table 1 Research design and result.

\begin{tabular}{lllll}
\hline Year & Period & Requested sample number & Collected sample number & Collected rate (\%) \\
\hline 2009 & February 20-24 & 3,200 & 1,042 & 33.8 \\
2010 & February 23-27 & 4,370 & 1,021 & 23.4 \\
2011 & February 24-28 & 4,370 & 1,261 & 28.9 \\
2012 & February 29-March 2 & 4,540 & 1,264 & 27.8 \\
2013 & March 5-7 & 4,448 & 1,262 & 28.4 \\
2014 & March 20-24 & 5,097 & 1,268 & 24.9 \\
\hline
\end{tabular}

Source: Initiative for Circular Flow Society (ICFS), 2014 [3].

Table 2 Comparison between the internet survey in 2014 and the census in 2010 by gender.

\begin{tabular}{lllll}
\hline Gender & Collected sample number & Collected rate (\%) & Population number by census & Population rate (\%) \\
\hline Male & 612 & 48.3 & $50,045,385$ & 48.0 \\
Female & 656 & 51.7 & $54,168,743$ & 52.0 \\
\hline Total & 1,268 & 100.0 & $104,214,128$ & 100.0 \\
\hline
\end{tabular}

Source: Initiative for Circular Flow Society (ICFS), 2014 [3] and Statistic Bureau, Ministry of Internal Affairs and Communications in Japan, 2010 [5]. 
Table 3 Comparison between the internet survey in 2014 and the census in 2010 by age.

\begin{tabular}{lllll}
\hline Age & Collected sample number & Collected rate (\%) & Population number by census & Population rate (\%) \\
\hline $20-29$ & 185 & 14.6 & $13,720,134$ & 13.2 \\
$30-39$ & 208 & 16.4 & $18,127,846$ & 17.4 \\
$40-49$ & 236 & 18.6 & $16,774,981$ & 16.1 \\
$50-59$ & 204 & 16.1 & $16,308,233$ & 15.6 \\
Over 60 & 435 & 34.3 & $39,282,934$ & 37.7 \\
\hline Total & 1,268 & 100.0 & $104,214,128$ & 100.0 \\
\hline
\end{tabular}

Source: Initiative for Circular Flow Society (ICFS), 2014 [3] and Statistic Bureau, Ministry of Internal Affairs and Communications in Japan, 2010 [5].

Table 4 Comparison between the internet survey in 2014 and the census in 2010 by area.

\begin{tabular}{lllll}
\hline Area & Collected sample number & Collected rate (\%) & Population number by census & Population rate (\%) \\
\hline Hokkaido/Tohoku & 163 & 12.9 & $12,218,199$ & 11.7 \\
Kanto/Keihin & 410 & 32.3 & $35,598,740$ & 34.2 \\
Chubu & 228 & 18.0 & $18,360,182$ & 17.6 \\
Kinki & 189 & 14.9 & $16,919,182$ & 16.2 \\
Chugoku/Shikoku & 141 & 11.1 & $9,391,760$ & 9.0 \\
Kyushu/Okinawa & 137 & 10.8 & $11,726,065$ & 11.3 \\
\hline Total & 1,268 & 100.0 & $104,214,128$ & 100.0 \\
\hline
\end{tabular}

Source: Initiative for Circular Flow Society (ICFS), 2014 [3] and Statistic Bureau, Ministry of Internal Affairs and Communications in Japan, 2010 [5].

Following shows prefectures which each area includes:

Hokkaido/Tohoku: Hokkaido, Aomori, Iwate, Miyagi, Akita, Yamagata, Fukushima;

Kanto/Keihin: Ibaraki, Tochigi, Gunma, Saitama, Chiba, Tokyo, Kanagawa, Yamanashi;

Chubu: Niigata, Toyama, Ishikawa, Fukui, Nagano, Gifu, Shizuoka, Aichi, Mie;

Kinki: Shiga, Kyoto, Osaka, Hyogo, Nara, Wakayama;

Chugoku/Shikoku: Tottori, Shimane, Okayama, Hiroshima, Yamaguchi, Tokushima, Kagawa, Ehime, Kochi;

Kyusyu/Okinawa: Fukuoka, Saga, Nagasaki, Kumamoto, Oita, Miyazaki, Kagoshima, Okinawa.

mark, was launched. The project was subsidized by METI, and its operation was managed by four companies, including INTAGE Research Inc., Japan Environmental Management Association for Industry (JEMAI), Asatsu-DK Inc. (ADK), Nippon Cultural Broadcasting Inc., and was supervised by CFP offset committee, in which the author of this paper chaired [6].

Following explains the framework of Acorn point system and the brief business profiles of various interest parties or stakeholders.

\subsubsection{Framework of Acorn Point System}

First of all, the goal of Acorn point system is to promote reduction of carbon dioxide. This is a three-stage system, comprising of CFP mark, Acorn mark and Acorn point mark stage.

\subsubsection{Stage of CFP Mark}

The CFP mark was shown in Fig. 1. First, the company, which wants to attach Acorn point mark on a product they make and participates in this project, is required to measure the volume of all carbon dioxide emissions exhausted in all the production processes and then to calculate the volume of the emission of each product. This calculation is named by CFP. The product which CFP was completed is permitted to put CFP mark on the product. CFP mark is expressed in the numerical value of exhausted $\mathrm{CO}_{2}$ volume per product. In Fig. 1, $10 \mathrm{~g}$ of CFP mark indicates that this product exhausts $10 \mathrm{~g} \mathrm{CO}_{2}$ per product.

\subsubsection{Stage of Acorn Mark}

In order to attach Acorn mark on a product, 


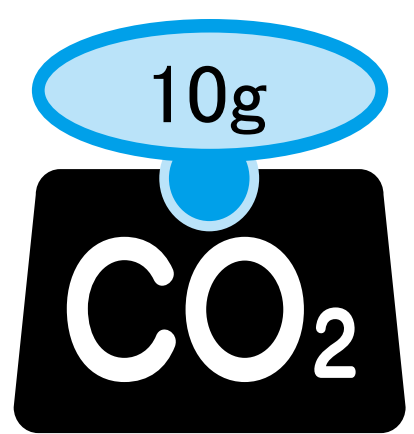

Fig. 1 CFP mark.

Fig. 2 Acorn mark.
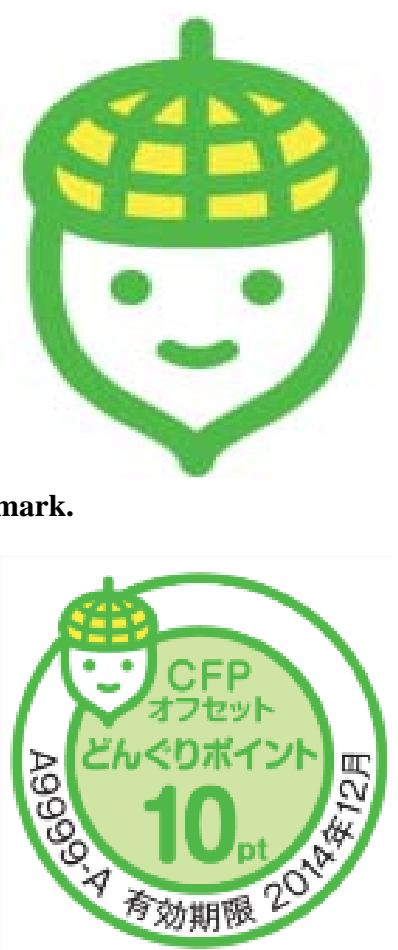

Fig. 3 Acorn point mark.

the company must offset the same $\mathrm{CO}_{2}$ volume by means of the carbon offset program, such as tree planting or installing energy-saving facilities. In this way, the offset product is permitted to attach Acorn mark as shown in Fig. 2.

\subsubsection{Stage of Acorn Point Mark}

The Acorn point mark was shown in Fig. 3. The company can attach Acorn point mark by paying two types of charges to CFP offset point committee, which is managing Acorn point system. First is point charge, in which one point means one yen. If a company wants to attach 10 points each on 100 products, it must pay 1,000 yen to the committee. And second is the commission fee for office administration job at the committee. This commission fee is the same amount of money as the point fee. In total, the company which attaches 10 points to their product must pay 20 yen to the committee. In addition to the company commission, the committee is also subsidized by METI.

\subsubsection{Stakeholders of Acorn Point System}

To make this scheme successful, participation of various stakeholders is inevitable. Acorn point supplier, Acorn point community, Acorn point supporter, Acorn point exchanging commodity supplier, Acorn point environmental contribution group and CFP offset point committee are all inevitable.

\subsubsection{Acorn Point Supplier}

Acorn point suppliers can attach Acorn point mark to their products and services. They can select either attaching the point seal on the product or giving the point card at the product and service purchase. Actually, the company conducting the environmental bus tour gives Acorn point card to the tour participants.

\subsubsection{Consumer}

When consumers purchased products, which Acorn point suppliers have attached Acorn point mark, they agree to the purpose of Acorn point system and give the mark to Acorn point community or Acorn point supporter.

\subsubsection{Acorn Point Community}

Acorn point communities, some school for example, Parent-Teacher Association (PTA) [7] collect Acorn point mark at the purchase of acorn point products or services. They exchange Acorn point mark to environmentally friendly products or services, which Acorn point exchanging commodity suppliers provide, or they donate the equivalent value of money to Acorn point environmental contribution group.

\subsubsection{Acorn Point Supporter}

Acorn point supporters help Acorn point communities collect Acorn point mark. For example, a retailer placing Acorn point mark collection box in his shop sends the point marks to Acorn point community. 
This retailer is an Acorn point supporter.

\subsubsection{Acorn Point Exchanging Commodity} Supplier

Acorn point exchanging commodity supplier provides the products/services to the Acorn point communities. They must provide environmentally friendly products or services to the acorn point communities.

\subsubsection{Acorn Point Contribution Group}

Acorn point contribution groups make use of the acorn point for the environmental activity fund.

\subsubsection{CFP Offset Point Committee}

CFP offset point committee takes charge of all administration and management about the acorn mark system. It judges all stakeholders, like Acorn point supplier, Acorn point community and so on. It permits that Acorn point suppliers issue acorn point mark to their products. And also, it delivers the products/services to Acorn point communities when the products/services are requested for the points exchange, and it gives money to Acorn point contribution group when Acorn point communities want to donate for environmental activities conducted by Acorn point contribution groups.

\subsubsection{Supporting Companies}

Thirteen companies participated as Acorn point supporting suppliers, as listed in Table 5 . And two of them, Aigamo Farm Onogoe and Pasona Nouentai were agricultural producers.

Following shows each suppliers' brief business profile.

\subsubsection{Nonprofit Organization-Sapporo}

\section{Convention Network [8]}

The organization was originally established by the group of 76 local companies in Sapporo area to facilitate region's economy, and in 2003 it officially started with the name of Sapporo Convention Network. The organization enthusiastically works on environment related educational events. In the recent example case, they designed and carried out environmental facilities visiting bus tour. Acorn point was attached to the tour ticket with point label card and handed to tour participants before riding. Just before the bus tour ending, passengers were informed of Acorn point label card and the scheme, in which collected points are given to the Acorn point management bureau through Acorn point community's Hokkaido Green Purchase Network and then the bureau makes donation to Hokkaido Foundation for Earth Environment for their environmentally friendly activities. All the tour participants were in favor of this project and putting the point card in the box, and the points were donated to Hokkaido Foundation for Earth Environment.

Table 5 List of Acorn point suppliers in 2013.

\begin{tabular}{llll}
\hline No. & Company & Location & Product and service \\
\hline 1 & Nonprofit Organization-Sapporo Convention Network & Hokkaido & Bus tour \\
2 & Marutama Industry Corporation & Hokkaido & Plywood \\
3 & SG Moving Corporation & Tokyo & House-moving \\
4 & Decos Corporation & Tokyo & Heat insulator \\
5 & NIK Kankyo Corporation & Okayama & Waste collection service vendor \\
6 & Aigamo Farm Onogoe & Ibaraki & Polished rice, unpolished rice \\
7 & Pasona Nouentai & Tokyo & Bagna cauda sauce \\
8 & Asahi Kako Corporation & Aichi & Tableware for school meals \\
9 & Klean-tex Japan & Hyogo & Doormat \\
10 & Limited Liability Company Hibikkuu & Fukuoka & Tumbler \\
11 & Tamaya Corporation & Kyoto & Paper food tray \\
12 & Sony Mobile Communications Japan Incorporation & Tokyo & Smartphone \\
13 & Kusubashi Mon-ori Corporation & Ehime & Towel \\
\hline
\end{tabular}

Source: CFP Offset Point Committee, 2014 [6]. 


\subsubsection{Marutama Sangyo Corporation [9]}

Marutama Sangyo in Tsubetsu town in Hokkaido produces plywood using white fir grown in the region, and it also plants nursery trees for forest conservation. Acorn point attached plywood is sold to its buyers with full explanation of the point system together with the points-card by sales staff of Marutama Sangyo. The points were wisely used for the purchase of wooden toys, which were delivered to the kindergartens in Tsubetsu town through Tsubetsu Children's Association Support Liaison Council corroborated by Tsubetsu local government. Marutama Sangyo is also enthusiastically delivering the information appealing the importance of wood industry to the public.

\subsubsection{SG Moving Corporation [10]}

SG Moving is the transportation company to help client office moving. The company provides Acorn points card to the client at the time of office move, and the points are converted into cash and donated to the Green Tokyo Fundraising Campaign of Tokyo Metropolitan Government through the hands of employees of SG Moving and its partner companies. The information regarding the donation is shared with the client company, to which the points card has given and also each client's contribution is appreciated in the column of the public relation newsletters.

\subsubsection{Decos Corporation [11]}

Decos attached Acorn point on their heat insulating building material made from recycled papers. The heat insulating material by Decos is called cellulose insulation, and emission of carbon dioxide is very small at the manufacturing process comparing to other heat insulators using such chemicals, as glass fiber or urethane, and it is flame-resistant and has no emission of toxic chemical substance. In spite of many more advantages than other heat insulators, its market penetration is very small due to limited awareness in Japan. Decos participated in Acorn point project in order to increase public awareness of their product advantages. Points are provided to the wooden house purchaser, who used Decos heat insulating materials. Decos also built up friendship of building community for the wooden house purchasers called "Peace of mind gathering", which collected the points, purchased nursery trees and planted them.

\subsubsection{NIK Kankyo Corporation [12]}

NIK Kankyo is a waste collection and delivery company. It gives the client Acorn points, and envelops with which the points are sent to Acorn point community, Kurashiki Environment Learning Center. The results are that the learning center purchased birdwatching telescopes in exchange for Acorn points and donated it to the kindergartens in the city.

In Japan, waste collection and delivery companies are generally regarded low in the social status, and NIK Kankyo rather tried to appeal its positive image by participating in environmental consideration projects, such as carbon dioxide reduction activities including planting trees in collaboration with local community. Acorn point project is one of those environmental consideration activities.

\subsubsection{Aigamo Ducks Farm Onogoe [13]}

The company is a rice producer and it uses Aigamo ducks for weeding field instead of using herbicide, thus implementing environmentally friendly farming practice.

Acorn points attached rice packages were sold at Tokyo Skytree Skytown event. Collected points were used for the activities at Minami Souma Agri Park, which is the junior and senior high-school students' natural energy learning center built in the area devastated by 2011 East Japan Great Earthquake.

\subsubsection{Pasona Nouentai [14]}

Pasona Nouentai produces vegetables and Italian cuisine's Bagna càuda sauce. They attached Acorn point on their sauce. The points are collected in the box placed at the store handling Pasona Nouentai's products, and they are given to the nonprofit organization which sells environment education materials and implements environment education programs. According to the recent case, the nonprofit 
organization used the points for donation to the conservation group for Blakiston's fish owl, the species in danger of extinction.

\subsubsection{Asahi Kako Corporation [15]}

Asahi Kako manufactures dishes. They attached points to the dishes for kindergarten kids devised with great care in terms of safety and ease of use. According to the recent case, the points were used for the donation of wooden blocks, which were delivered to kindergartens through nonprofit organization.

\subsubsection{Klean-tex Japan [16]}

Klean-tex Japan attached Acorn points on their doormat product, and placed the point collection box at the department stores handling the products. The points were used to exchange environment education materials and delivered to the local elementary schools.

\subsubsection{Limited Liability Company HiBiQoo [17]}

HiBiQoo LLC produces tumblers using plant-derived materials, potters stone and clay instead of chemical materials. And they attached Acorn point label to this product. Normally, potter production requires $800{ }^{\circ} \mathrm{C}$ heat for $8 \mathrm{~h}$, however, HiBiQoo tumbler requires $200^{\circ} \mathrm{C}$ heat for $1 \mathrm{~h}$ in its production, thus emission of carbon dioxide is much smaller. Acorn point attached tumbler was picked as the mementos at the Kitakyushu marathon race and the points were used to purchase acorn nursery trees to be planted in Kitakyushu City.

\subsubsection{Tamaya Corporation [18]}

Tamaya attached Acorn point label on their paper tray product for the plates used for fried noodles and pasta at the community events. Acorn point labeled trays were collected and the points were exchanged for environmentally friendly stationary products, which are used in the community activities.

\subsubsection{Sony Mobile Communications Japan} Incorporation [19]

Sony Mobile Communications gave Acorn points to their new smartphone purchasers. The difference from other Acorn point system is that the point was given to the purchasers but not the product itself. The purchaser of the product accessed to the specified website, visited the point selection screen by typing the serial code numbers given for the product purchaser, and picked favorable menu from the list, which includes several choices like tree-planting, natural energy facility and so on. This new donation style was highly evaluated by consumers.

\subsubsection{Kusubashi Mon-ori Corporation [20]}

Kusubashi Mon-ori manufactures towels from organic cotton, which is grown under the strict control of limited agrichemicals or fertilizers use and thus is well considered of safety and environment. Their towels were sold at the Acorn point event at Tokyo Skytree, and same as Aigamo Ducks Farm Onogoe, points were used for donation to the activities of Minamisoma Agri-Bio-Park through nonprofit organization of Acorn point community.

\section{Results and Discussion}

\subsection{Environmental Consciousness Held by Consumers}

Table 6 shows Japanese consumers' selection reasons for food product surveyed in the annual internet research conducted in February/March from 2009 to 2014 [21, 22]. Respondents have selected three most important reasons from the different choices. The most important reason is the price and it had been selected by more than $60 \%$ of respondents every year. After 2010, the price had been ranked first, followed by taste, freshness, safety, nutrition, trustworthy company and environmental consideration, and few respondents picked such answers as social contribution activity, package color and design. As for 2009, freshness and safety were ranked high due to the effect of food poisoning on imported Chinese chilled dumplings and vegetables contaminated by insecticide or the residue of pesticide. Environmental consideration had been the 7th in ranking. It picked up in 2009 because of positive effect of the 2008 G8 Hokkaido Toyako Summit [23] held in Japan, however declined again after that. 
Table 6 Trend of the reason to choose food by Japanese.

\begin{tabular}{|c|c|c|c|c|c|c|}
\hline Reason & 2009 & 2010 & 2011 & 2012 & 2013 & 2014 \\
\hline Price & 62.3 & 63.8 & 63.2 & 64.9 & 65.9 & 61.3 \\
\hline Taste & 51.4 & 58.4 & 58.0 & 58.7 & 60.5 & 60.3 \\
\hline Freshness & 59.8 & 57.5 & 56.5 & 52.5 & 50.3 & 51.3 \\
\hline Safety & 56.0 & 47.1 & 41.8 & 35.3 & 31.9 & 28.4 \\
\hline Nutrition & 18.1 & 18.5 & 25.4 & 24.1 & 23.1 & 25.9 \\
\hline $\begin{array}{l}\text { Corporate } \\
\text { reliability }\end{array}$ & 13.0 & 13.2 & 11.1 & 11.9 & 12.3 & 10.8 \\
\hline Environment & 9.2 & 7.0 & 4.2 & 4.4 & 5.1 & 6.0 \\
\hline $\begin{array}{l}\text { Social } \\
\text { contribution }\end{array}$ & - & 0 & 0.8 & 1.0 & 0.6 & 0.8 \\
\hline Package design & 0.8 & 0.6 & 1.1 & 0.6 & 1.1 & 0.5 \\
\hline Others & 1.7 & 1.1 & 0.8 & 1.5 & 1.5 & 0.9 \\
\hline Unknown & 1.7 & 2.4 & 2.3 & 3.3 & 2.4 & 4.5 \\
\hline
\end{tabular}

Source: Initiative for Circular Flow Society (ICFS), 2014 [3].

Price and product quality attributes were ranked high not only in the food product but also in other product categories. Table 7 shows the results of a survey conducted in 2012 [24]. Soft drinks, liquors, daily commodities and medicine had the same results across the category. This showed that products' functional benefits and price were more important than the environment, and were identical to the food product results.

With regard to electronic appliances and cars, survey results showed that no machine trouble for long time and low running cost were ranked high. However, the respondents placed higher importance on price and quality than environment related attributes, which was exactly the same results as other categories.

\subsection{Environmental Awareness}

With regard to the environmental consciousness held by corporations, the survey conducted by Ministry of Environment was quoted [25]. The survey was conducted among 827 corporate members who are listed on the 1st and 2nd tiers of Tokyo stock exchange and 2,173 non-listed corporations and business operations with more than 500 employee size, which are in total 3,000 respondent corporations and answers were obtained from total 1,161 corporations or $38.7 \%$ in survey completion rate. Results are shown in Tables 8 and 9.

Table 8 summarizes corporate activities in relation to environmental consideration. The $80.5 \%$ of corporations are gathering environmental load data, $63.8 \%$ are acquiring certificate of environment management system, such as ISO14001, 58.0\% have sections in charge of environment related matters, and $52.8 \%$ conduct environment related educational program among employees at least once a year, thus many corporations are engaged in environmental activity.

Table 9 shows the responses to the question whether the environmental consideration is incorporated in the performance appraisal and the personnel assessment. Number of those incorporating it into performance appraisal and personnel assessment are $21.0 \%$ and $10.5 \%$, respectively and those incorporating it in neither of them are $74.1 \%$. Table 9 shows some progress in activities relating environmental consideration, however, it is inferred that environmental consideration is not regarded as suitable measure to be reflected on both assessments. That is to say, there still is a mind-set at the bottom that contributing to the environment does not necessarily have a positive effect on sales volume or profit increase. 
Table 7 The reason to choose products by Japanese in 2012.

\begin{tabular}{|c|c|c|c|c|c|c|c|c|}
\hline \multirow{2}{*}{ Product } & \multicolumn{8}{|c|}{ Ranking of reason (\%) } \\
\hline & $1 \mathrm{st}$ & 2nd & 3rd & 4th & 5th & 6th & 7th & 8th \\
\hline \multirow[t]{2}{*}{ Food } & Price & Taste & Freshness & Safety & Nutrition & Reliability & Environment & $\begin{array}{l}\text { Social } \\
\text { contribution }\end{array}$ \\
\hline & 64.9 & 58.7 & 52.5 & 35.3 & 24.1 & 11.9 & 4.4 & 1.0 \\
\hline \multirow{2}{*}{$\begin{array}{l}\text { Febrifuge/ } \\
\text { alcoholic drinks }\end{array}$} & Taste & Price & Safety & $\begin{array}{l}\text { Stress } \\
\text { reduction }\end{array}$ & Reliability & $\begin{array}{l}\text { Cool } \\
\text { sensation }\end{array}$ & Environment & Nutrition \\
\hline & 65.6 & 61.1 & 30.7 & 25.8 & 17.0 & 16.5 & 6.5 & 4.7 \\
\hline \multirow{2}{*}{$\begin{array}{l}\text { Convenience } \\
\text { goods }\end{array}$} & Price & Good quality & Easy to use & Safety & Environment & $\begin{array}{l}\text { Proper } \\
\text { quantity }\end{array}$ & Reliability & $\begin{array}{l}\text { Package } \\
\text { design }\end{array}$ \\
\hline & 67.8 & 50.1 & 25.9 & 22.7 & 22.7 & 19.6 & 9.9 & 2.3 \\
\hline \multirow[t]{2}{*}{ Nostrum } & Heal quickly & $\begin{array}{l}\text { Have no side } \\
\text { effects }\end{array}$ & Price & $\begin{array}{l}\text { Easy to } \\
\text { ingest }\end{array}$ & Reliability & Proper size & Environment & $\begin{array}{l}\text { Social } \\
\text { contribution }\end{array}$ \\
\hline & 68.0 & 58.0 & 35.7 & 31.5 & 26.5 & 3.4 & 3.4 & 0.7 \\
\hline \multirow{2}{*}{$\begin{array}{l}\text { Home electric } \\
\text { appliances }\end{array}$} & Long-life & Price & $\begin{array}{l}\text { Low running } \\
\text { cost }\end{array}$ & Safety & Reliability & Proper size & $\begin{array}{l}\text { Noise and } \\
\text { vibration }\end{array}$ & Multifunction \\
\hline & 73.0 & 53.2 & 52.1 & 22.7 & 16.2 & 12.1 & 12.0 & 9.9 \\
\hline \multirow[t]{2}{*}{ Automobile } & Fuel efficient & Long-life & Price & $\begin{array}{l}\text { Smooth } \\
\text { ride }\end{array}$ & Safety & Proper size & $\begin{array}{l}\text { Design and } \\
\text { color }\end{array}$ & Environment \\
\hline & 64.9 & 56.2 & 37.4 & 24.9 & 20.0 & 14.7 & 11.6 & 8.2 \\
\hline
\end{tabular}

Source: Initiative for Circular Flow Society (ICFS), 2012 [24].

Table 8 Activities regarding environmental consideration by corporations.

\begin{tabular}{ll}
\hline Environmental activities & Percentage (\%) \\
\hline Gathering environmental load data & 80.5 \\
Acquiring certificate of environment management system & 63.8 \\
Having sections in charge of environment related matters & 58.0 \\
Conducting environment related educational program among employees & 52.8 \\
\hline
\end{tabular}

Source: Ministry of the Environment in Japan, 2014 [25].

Table 9 Incorporation of environmental consideration perspectives into company's performance appraisal and personnel assessment.

\begin{tabular}{ll}
\hline Incorporation of environmental consideration perspectives & Percentage (\%) \\
\hline For performance appraisal & 21.0 \\
For personnel assessment & 10.4 \\
Neither incorporated & 74.1 \\
\hline
\end{tabular}

Source: Ministry of the Environment in Japan, 2014 [25].

Taking aforementioned circumstances into consideration, inevitable take away is the critical importance of both efforts in increasing general environment consciousness by heavy-up environment education programs and some innovative and effective set-up of driving environment perception change even among limited understanding people. In other words, it is essential to develop a mechanism, which can better mix instinctively-emotional-driven benefit which is not necessarily environmental with environmental context-driven sophisticated rational values, and then make it applicable to actual business scheme with environmental consideration.

\subsection{Noteworthy Points on Project Accomplishments}

3.3.1 Proactive Participation from Environmentally Friendly Product Company

Noteworthy point number one is that project which had proactive participation from environmentally friendly product companies. They attached Acorn points on their environment considering products and services. As mentioned above in this system, Acorn 
points are used for environmental contribution through carbon offsets. However, actually some products have two-stage or maybe three-stage contributions to market environment. Let's look at the case of Decos again. Firstly, Decos produces heat insulator, which is energy saving, flame resistant and no toxic chemical substance emission materials. Secondly, their insulator production is based on reusing paper materials from recycling system. And thirdly they participate in carbon offsetting by attaching Acorn point on their already environmental product.

It is quite clear that those suppliers participation in the Acorn point system is based on their good marketing for environmentally friendly products. Their strong commitments to tackle on the solution for environmental problems must be highly appreciated.

Firstly, look at the case of the building of corporate image and increase of awareness of local wood industry by comprehensive and consistent message communication. As previously mentioned, Marutama Sangyo produces plywood using white fir grown in the region and it also plants nursery trees for forest conservation, and Acorn points attached on their plywood were finally exchanged to wooden toys for kindergarten children. The message for local wood industry awareness infers that the company survives with local community support and understanding of wood industry which is sustained by constant efforts of environment protection. And the corporate message is that Marutama Sangyo always commits caring about the community and continuing communication of good value of wood.

Secondly, look at the case of the building of corporate image and client customer relationship. By putting the collaborating companies on Acorn point environmental activity in their newsletter article, SG Moving communicates that they are proactively contributing to the environment together with their client companies. This leads to increasing favorable image of the company, as well as building strengthened relationship with their corporate clients. This is a good example of industrial marketing with environmental consideration.

\subsubsection{Consumer Perception to the Project}

Consumer opinions about the Acorn point system was collected among visitors at the Acorn point product selling event in Tokyo Skytree town.

Tokyo Skytree, the world highest $634 \mathrm{~m}$ height radio tower built in May 2012, has two observatory decks at $350 \mathrm{~m}$ and $450 \mathrm{~m}$ height, respectively. Three-hundred restaurants/shops and aquarium are opening beneath the tower, and the area is one of the most popular spots in Tokyo. The Sky-town square attracts many visitors. Consumer hearings were conducted there regarding purchase intention for Acorn point products and many showed positive intention. The major reasons were that want to support for environment; and Acorn concept is a good fit to the activity, effective to carbon dioxide reduction, good-for-health endorsement by Acorn label, effective program for reconstruction of earthquake disaster area, good local community support, wishing for becoming much greater scale activity, cute Acorn mark and so on.

Meanwhile, some negatives reasons were that Acorn mark does not communicate product quality or price, however it is worth considering if it's reasonably priced, it is not sure if it's really economically friendly because of a bit complicated Acorn label qualification criteria, and where to get a product is not clear.

Consumers' perception is actually very interesting in terms of several aspects.

First, as environment consideration project concept, Acorn point system framework was overall positively accepted.

Second, many showed their willingness to support environmental protection and also local communities with severe damage from Northeastern earthquake.

Third, health is an important key word to keep in mind. 
Fourth, however, some of them showed concerns about the activity because of difficulty to understand the participant qualification criteria.

\section{Conclusions}

It was revealed from the internet survey that consumers chose a product from price, quality and functions such as taste and health rather than environment. This tendency is common to not only the food products but also all other products, including the home electric appliances and the car, because consumers purchase a product to do life wealthily. However, the psychological and mental feeling for the products the Acorn mark attached and the sense of accomplishment for the contribution of the earthquake disaster revival may become the promotion factor of the purchase. The author found that such various benefits promoted the consumers' purchase throughout the implementation of the Acorn point project.

On the other hand, companies work for the increase of sales and profit. Companies think that the environmental consideration is unrelated to profit and the sales, and therefore there are many companies which do not include environment consideration in job performance evaluation and personnel evaluation. However, when they understand that the environmental consideration will be connected with sales and profit, they move toward the business strategy with environmental consideration. I found that understanding such benefits by companies promoted their environmental consideration throughout the implementation of the Acorn point project.

\section{Future Directivity}

In order to convince people to use environmentally friendly products, a general suggestion is increasing opportunities of environmental education programs, which supposedly enhance environmentally friendly consciousness. However, the frustrating reality is that in spite of such acquired knowledge for importance of environmental problems, it does not necessarily lead to the overall environmental awareness improvement and most importantly lead to the actual action movement for better environment among people.

When taking the above into consideration, it is essential to look deep into consumer motivation factors or psychological trigger which can effectively lead to actual behavior in environment improvement.

In addition, as an important learning from the Acorn Point System Project, the involvement of multiple interest parties as well as the local community in the project was very effective to promote the use of the environmentally friendly products with the reason that the participation of various interest parties increases the project reliability perception.

Also for the earth environment, it is a too big matter for the individual to see the effect of single purchase of environmentally friendly product, however, it looks more feasible when people work together as a local area community project. Thus, it is easy to see the outcome of the individual environmentally friendly product purchase through community implemented offset point system.

Finally, it is strongly recommended that this trinity approach of corporate-individual-community combined activity project should be further exploited in nationwide scale. At the same, we need to keep in mind that product should be appealed to always go together with the rational environmentally friendliness and its non-environmental hedonistic benefits.

\section{References}

[1] Ministry of the Environment in Japan. 2012. Green Market Plus Workshop Report towards Further Greening of Market.

[2] Ministry of Economy, Trade and Industry in Japan. 2013. "General Outline of Visualization System Cooperation Business in the 2013 Fiscal Year.” Accessed February 17, 2016. http://warp.da.ndl.go.jp/info:ndljp/pid/8315894/www. meti.go.jp/information/publicoffer/kobo/k130722002.html.

[3] Initiative for Circular Flow Society (ICFS). 2014. ICFS Researching Report about Environment, Economy and Energy in 2014. INTAGE Research Inc., Tokyo. 
[4] Statistic Bureau, Ministry of Internal Affairs and Communications in Japan. 2005. "The National Population Census 2005.” Accessed February 18, 2016. http://www.e-stat.go.jp/SG1/estat/GL08020101.do?_toG L08020101_\&tstatCode $=000001007251 \&$ requestSender= search.

[5] Statistic Bureau, Ministry of Internal Affairs and Communications in Japan. 2010. "The National Population Census 2010.” Accessed February 18, 2016. http://www.e-stat.go.jp/SG1/estat/NewList.do?tid=00000 1039448.

[6] Carbon Footprint Offset Point Committee in Japan. 2014. Annual Report about Acorn Point Project in 2013.

[7] Ministry of Education, Culture, Sports, Science and Technology in Japan. 2010. "The Law about the Mutual Aid of Parent-Teacher Association and Youth Educational Group.” Accessed February 17, 2016. http://law.e-gov. go.jp/htmldata/H22/H22HO042.html.

[8] Nonprofit Organization-Sapporo Convention Network. 2004. "Introduction of Nonprofit Organization-Sapporo Convention Network.” Accessed November 22, 2015. http://www.sapporo-convention.net/.

[9] Marutama Sangyo Corporation. 2009. "Introduction of Marutama Sangyo Corporation.” Accessed November 22, 2015. http://www.marutama-ind.com/.

[10] SG Moving Corporation. 1999. "Introduction of SG Moving Corporation.” Accessed November 22, 2015. http://www.sagawa-mov.co.jp/.

[11] Decos Corporation. 2011. "Introduction of Decos Corporation.” Accessed November 22, 2015. http://www.decos.co.jp/index.html.

[12] NIK Kankyo Corporation. 2014. "Introduction of NIK Kankyo Corporation.” Accessed November 22, 2015. http://www.kct.ne.jp/ naikai/.

[13] Aigamo Farm Onogoe. 2016. "Introduction of Aigamo Farm Onogoe.” Accessed February 17, 2016. http://onogoe.jp/.

[14] Pasona Nouentai. 2012. "Introduction of Pasona Nouentai.” Accessed November 22, 2015. http://www.pasona-nouentai.co.jp/.

[15] Asahi Kako Corporation. 2015. "Introduction of Asahi Kako Corporation.” Accessed November 22, 2015. http://www.asahi-kako.co.jp/.

[16] Klean-tex Japan Incorporation. 2015. "Introduction of Klean-tex Japan Inc..” Accessed November 22, 2015. http://www.kleen-tex-japan.co.jp/.

[17] Limited Liability Company HiBiQoo. 2011. "Introduction of Limited Liability Company HiBiQoo." Accessed November 22, 2015. http://hibiqoo.co.jp/.

[18] Tamaya Corporation. 2013. "Introduction of Tamaya Corporation.” Accessed November 22, 2015. http://www.tamayakk.co.jp/.

[19] Sony Mobile Communications Japan Incorporation. 2016. "Introduction of Sony Mobile Communications Inc.." Accessed February 17, 2016. http://www.sonymobile.co.jp/.

[20] Kusubashi Mon-ori Corporation. 2005. "Introduction of Kusubashi Mon-ori Corporation.” Accessed November 22, 2015. http://www.kusubashi.jp/.

[21] Tetsuo, N. 2013. "How to Diffuse Life Cycle Thinking into Agri-Food Industries and Citizens: A Perspective from Consulting Services in Japan.” In Proceedings of Regional Conference and Workshop of Life Cycle Thinking on Energy, Food and Agriculture in Asia.

[22] Tetsuo, N. 2015. "Study on Life Cycle Benefit Assessment as a Solution Aiding Tool for the Environmental Problems." In Proceedings of the 3rd International Conference on Adaptive and Intelligent Agroindustry (ICAIA).

[23] Ministry of Foreign Affairs of Japan. 2007. "G8 Hokkaido Toyako Sumit.” Accessed February 17, 2016. http://www.mofa.go.jp/policy/economy/summit/2008/ind ex.html.

[24] Initiative for Circular Flow Society (ICFS). 2012. ICFS Researching Report about Environment, Economy and Energy in 2012. INTAGE Research Inc., Tokyo.

[25] Ministry of the Environment in Japan. 2014. Researching Report about Environmentally Friendly Behavior of Japanese Companies in 2012. 